\title{
BILL MUNDY THEORY, EFFECTIVE RAKE ANGLE CUTTING TOOLS IN COPPER ALLOYS
}

\section{TEORÍA DE BILL MUNDY Y EL ÁNGULO EFECTIVO DE ATAQUE DE HERRAMIENTAS DE CORTE EN ALEACIONES DE COBRE}

\author{
Juan Miguel Godoy R. ${ }^{1} \quad$ Jorge Vergara D. ${ }^{1} \quad$ Percy Oviedo O. ${ }^{1} \quad$ Martín Quispe Y. $^{1}$ \\ Edward Gallardo M. ${ }^{1} \quad$ Leandro Ramírez H. ${ }^{1}$
}

Recibido 23 de junio de 2006, aceptado 16 de agosto de 2007

Received: June 23, 2006 Accepted: August 16, 2007

\begin{abstract}
RESUMEN
Revistas como American Machinist y Manufacturing Engineering han explicado la Teoría de Bill Mundy y el ángulo efectivo de ataque en herramientas de corte utilizadas en aceros al carbono, aceros aleados, hierro fundido, aluminio y acero inoxidable. En este trabajo, esta teoría es aplicada a herramientas de corte usadas para latón y bronce y sus resultados son comparados con los ángulos de ataque recomendados por los fabricantes de herramientas de corte.

El ángulo de ataque efectivo se obtiene del ensayo de tracción del material a ser mecanizado. Los ángulos de las herramientas fueron hechos en una máquina universal de afilar Heiler. El consumo de potencia fue medido en un torno CNC. El consumo de potencia con herramientas de corte comerciales con ángulos de corte recomendados por la bibliografía existente fue comparado con las herramientas afiladas con el ángulo de corte efectivo obtenido a través de la teoría de Bill Mundy. Los resultados indican que el consumo de potencia es un 10\% menor para las herramientas afiladas con el ángulo efectivo recomendado por la teoría.
\end{abstract}

Palabras clave: Manufactura, herramientas de corte, latón, bronce.

ABSTRACT

Magazines like American Machinist and Manufacturing Engineering, have explained the Bill Mundy theory about the effective rake angle of cutting tools. These articles show the effective rake angle of cutting tools for carbon steel, steel, alloys, cast iron, aluminium and stainless steel. In the present work the theory is applied to cutting tools used in brass and bronze.

The effective rake angle for these materials was obtained with the tensile stress test. The rake angles in the cutting tools were made in a Universal Grinding Machine Heiler. Finally, the power consumption was measured in a CNC Lathe. Tools with commercial rake angles from bibliography were compared with tools with the experimental effective rake angle obtained from the Bill Mundy Theory. The results show that the power consumption is about 10\% lower for tools with the experimental effective rake angle.

Keywords: Manufacturing, cutting tools, brass, bronze.

\section{INTRODUCTION}

Copper is a soft material and when it is mechanized produces a plastic and continuous chip. The cutting tool must have a suitable geometry to obtain a good surface quality but the manufacturers offer cutting tools for materials group. The Bill Mundy theory said that each material needs the right rake angle tool when it is mechanized. He relates the rake angle of each material with the angle formed in the slipping plane of the rupture cone probe after the tensile strength test [1].

In this work, it was made the tensile strength test in brass and bronze probes. It was determined the experimental rake angle for these materials and some cutting tools were sharpened with these experimental effective rake angles.

1 Universidad de Tarapacá. Escuela Universitaria de Ingeniería Mecánica. Casilla 6-D. Arica, Chile. E-mail: jmgodoy@uta.cl 
Brass and Bronze bars with 19 [mm], diameter, were turned in a Lathe with cutting tools recommended in the literature and by the manufacturers and cutting tools sharpened with the experimental effective rake angle. It was measured the power consumption for different feed and cutting velocities. The results indicate power consumption $10 \%$ lower for the tools with the experimental rake angle recommended by Bill Mundy.

Other work related with drilling and tapping tools sharpened with the experimental effective rake angle calculated from Bill Mundy theory showed similar decrease power consumption when compared with commercial drilling and tapping tools [2].

\section{EXPERIMENTAL PROCEDURE}

A Universal Hardness Machine SKF was used to measure the hardness of the alloys used in this work. Emission Spectroscopy Baird determined the chemical composition of the copper alloys.

The Tensile Stress Test was made in a Universal Testing Machine Kratos.

The samples were machined in a CNC Lathe Denford ORAC with $0,37 \mathrm{~kW}$. The power consumption was measured with a Wattmeter.

A Universal Grinding Machine Heiler was used to make the experimental rake angles in the cutting tools. The angles were measured in a Tool Microscope Carl Zeiss.

\section{Hardness}

The hardness of the different samples are indicated in table 1 .

Table 1. Brinell Hardness (HB) for the samples.

\begin{tabular}{|c|c|}
\hline \multicolumn{2}{|c|}{ Brass } \\
\hline Sample & HB \\
\hline B1 & 142 \\
\hline B2 & 121 \\
\hline B3 & 142 \\
\hline B4 & 121 \\
\hline \multicolumn{2}{|c|}{ Bronze } \\
\hline Sample & HB \\
\hline S1 & 100 \\
\hline S2 & 82 \\
\hline S3 & 139 \\
\hline S4 & 120 \\
\hline
\end{tabular}

\section{Chemical composition}

The chemical compositions of the samples are indicated in table 2 .

Table 2. Brass and Bronze chemical composition.

\begin{tabular}{|c|c|c|c|c|c|c|c|c|}
\hline \multirow{2}{*}{ Alloy } & \multicolumn{8}{|c|}{ Elements } \\
\hline & $\mathrm{Cu}$ & $\mathrm{Zn}$ & $\mathbf{N i}$ & $\mathrm{Fe}$ & Sn & $\mathbf{P b}$ & $\mathbf{P}$ & $\mathbf{S}$ \\
\hline \multicolumn{9}{|l|}{ Brass } \\
\hline B1 & 62 & 35 & & 0,1 & & 3,6 & & \\
\hline B2 & 60 & 35 & & 0,1 & 0,2 & 4,1 & & \\
\hline B3 & 62 & 34 & & 0,1 & & 4,1 & & \\
\hline B4 & 61 & 34 & & 0,2 & 0,2 & 4,5 & & \\
\hline \multicolumn{9}{|c|}{ Bronze } \\
\hline S1 & 83 & 2,9 & & & 6,5 & 7,4 & 0,2 & \\
\hline $\mathrm{S} 2$ & 78 & 0,6 & & & 6,5 & 14 & & 0,1 \\
\hline S3 & 89 & 0,2 & 1,1 & & 9,6 & & 0,1 & \\
\hline S4 & 81 & 0,6 & & & 9,0 & 9,7 & 0,1 & \\
\hline
\end{tabular}

\section{Tensile Stress}

The tensile stress of each sample was made according to ASTM B55 M-79. The results are indicated in table 3.

Table 3. Samples Tensile Stress.

\begin{tabular}{|c|c|}
\hline \multicolumn{2}{|c|}{ Brass } \\
\hline Sample & Tensile Stress MPa. \\
\hline B1 & 468 \\
\hline B2 & 400 \\
\hline B3 & 483 \\
\hline B4 & 397 \\
\hline \multicolumn{2}{|c|}{ Bronze } \\
\hline Sample & Tensile Stress MPa \\
\hline S1 & 343 \\
\hline S2 & 245 \\
\hline S3 & 350 \\
\hline S4 & 345 \\
\hline
\end{tabular}

\section{Experimental effective rake angle}

The effective rake angle $(\gamma)$ was calculated measuring the initial length $\left(\mathrm{L}_{\mathrm{o}}\right)$, final length $\left(\mathrm{L}_{1}\right)$ and the neck-down 
angle (B) obtained from the sample after the tensile stress test.

The value is calculated from the equation 2.1 [1].

$$
\cos \gamma=\left(\frac{l_{i}}{l_{f}}\right) \cos \beta
$$

$\gamma=$ effective rake angle

$l_{i}=$ probe long before tensile strength test

$l_{f} \ldots=$ probe long after tensile strength test

$\beta=$ angle in the rupture cone.

Table 4 shows the effective rake angles for brass and bronze obtained from this equation.

Table 4. Brass and Bronze effective rake angle.

\begin{tabular}{|c|c|c|c|}
\hline \multicolumn{4}{|c|}{ Brass } \\
\hline Sample & Lf mm & $\mathbf{B}^{\mathbf{0}}$ & $\boldsymbol{\gamma}^{\mathbf{0}}$ \\
\hline B1 & 81,6 & 4,30 & 40,2 \\
\hline B2 & 81,1 & 3,10 & 39,7 \\
\hline B3 & 79,6 & 8,10 & 38,9 \\
\hline B4 & 78,8 & 10,2 & 38,7 \\
\hline \multicolumn{4}{|c|}{ Bronze } \\
\hline Sample & Lf mm & $\mathbf{B}^{\mathbf{0}}$ & $\boldsymbol{\gamma}^{\mathbf{0}}$ \\
\hline S1 & 77,6 & 4,66 & 36,3 \\
\hline S2 & 72,6 & 4,19 & 30,8 \\
\hline S3 & 67,8 & 3,85 & 21,7 \\
\hline S4 & 70,3 & 3,92 & 27,9 \\
\hline
\end{tabular}

For copper and alloys, Larburu [3] recommends the following angles: incidence angle $\alpha: 8^{\circ}$ and rake angle $\gamma$ : $12^{\circ}$. Jütz, Scharkus and Lobert [4] recommend incidence angle $\alpha: 8^{\circ}$ and rake angle $\gamma: 14^{\circ}$. Sandvik Coromant [5] recommends angle $\alpha: 8^{\circ}$ and rake angle $\gamma: 10^{\circ}$.

\section{Cutting tool grinding}

The HSS cutting tools were grinding without nose radius in a Universal grinding machine. For the brass samples the incidence angle was $\alpha: 8^{\circ}$ and the effective rake angle was $\gamma: 40^{\circ}$.

For bronze samples the incidence angle was $\alpha: 8^{\circ}$ and the effective rake angles were $\gamma: 36^{\circ}, 31^{\circ}, 22^{\circ}$ and $28^{\circ}$ for S1, S2, S3 and S4 samples.
The information from Larburu and Jütz, Scharkus and Lobert was used to prepare two standard tools. In both cases, incidence angle $\alpha$ with $8^{\circ}$ was used.

\section{Power Test}

The CNC lathe was used at constant speed $2.000 \mathrm{rpm}$, with four feeds, $0.1,0.2,0.3$ and $0.4[\mathrm{~mm} / \mathrm{rev}]$. The cutting depth was $0,5[\mathrm{~mm}]$. The external diameter sample bar is $19[\mathrm{~mm}]$ and the cutting length was $30[\mathrm{~mm}]$. where Vc is the cutting velocity in [m/min], D the diameter of the bar (in this case $19 \mathrm{~mm}$ ) and the speed in rpm.

\section{RESULTS}

\section{Power Consumption at constant speed}

Three cutting tools were selected in each run for different bronze samples. They all have incidence angle $\alpha: 8^{\circ}$. The effective rake angles $\gamma$ were $12^{\circ}$ and $14^{\circ}$ according to literature $[3,4]$ and $36^{\circ}, 31^{\circ}, 22^{\circ}$ and $28^{\circ}$ for samples $S_{1}$, $\mathrm{S}_{2}, \mathrm{~S}_{3}$; and $\mathrm{S}_{4}$ according to Bill Mundy theory.

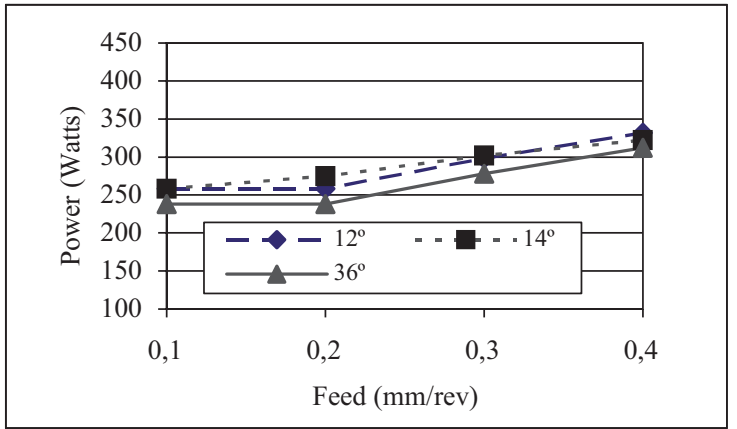

Figure 1. Power consumption versus feed for bronze $\mathrm{S}_{1}$.

The four runs indicate lower power consumption for the tool with rake angles made with the Bill Mundy theory. Figure 1 shows the run for sample $S_{1}$ with rake angle $\gamma: 36^{\circ}$. Power consumption is lower for the cutting tool according to Bill Mundy theory.

\section{Cutting tools with differents rake angles}

For brass, three cutting tools were selected in each run. They have an incidence angle of $\alpha: 8^{\circ}$ and rake angle $\gamma$ : $14^{\circ}[4]$ and $\gamma: 40^{\circ}$ for sample $B_{1}$

Figure 2 shows the curves for sample $\mathrm{B}_{1}$. The cutting tool with the effective rake angle obtained from Bill Mundy theory $\left(\gamma: 40^{\circ}\right)$ shows less power consumption. 


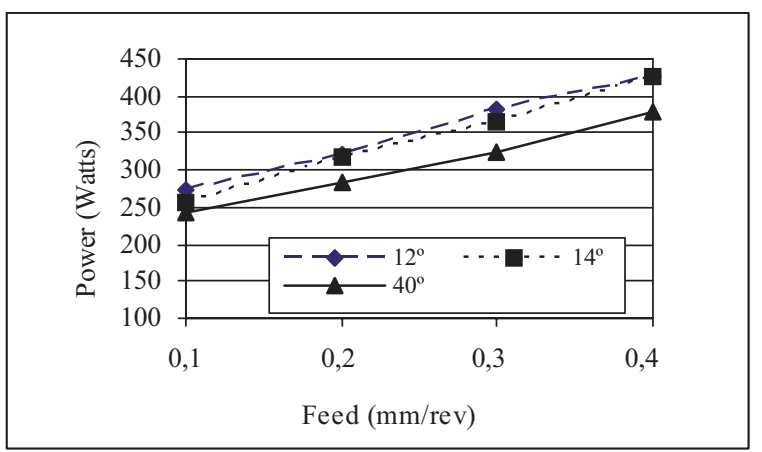

Figure 2. Power consumption versus feed for brass $B_{1}$. Cutting tools with differents rake angles.

\section{Power Consumption with variable speed}

A new set of experiments was made but now using the Manual of Sandvik Coromant [5] or high speed cutting tools with a rake angle $\gamma: 14^{\circ}$. This manual recommends different cutting velocities or variable speed for each feed. The cutting velocity relates to speed through equation 3.1 [6].'

$$
\text { Speed }=\frac{V c \cdot 1000}{D \cdot \pi}[\mathrm{rpm}]
$$

Where $\mathrm{Vc}$ is the cutting velocity in $[\mathrm{m} / \mathrm{min}], \mathrm{D}$ the diameter of the bar (in this case 19 [mm]) and the speed in rpm.

Table 5 shows for brass and bronze, the feed $(\mathrm{mm} / \mathrm{rev})$ and the recommended cutting velocity according to Sandvik. It also included the corresponding speed for $19 \mathrm{~mm}$ diameter bars.

Table 5. Brass and Bronze Cutting Data.

\begin{tabular}{|c|c|c|}
\hline \multicolumn{3}{|c|}{ Brass } \\
\hline Feed mm/rev & $\begin{array}{c}\text { Cutting } \\
\text { m/min }\end{array}$ & $\begin{array}{c}\text { Speed } \\
\text { rpm }\end{array}$ \\
\hline 0,2 & 115 & 1927 \\
\hline 0,3 & 100 & 1675 \\
\hline 0,4 & 85 & 1424 \\
\hline \multicolumn{3}{|c|}{ Bronze } \\
\hline $\begin{array}{c}\text { Feed } \\
\text { mm/rev }\end{array}$ & $\begin{array}{c}\text { Cutting } \\
\text { m/min }\end{array}$ & $\begin{array}{c}\text { Speed } \\
\text { rpm }\end{array}$ \\
\hline 0,1 & 85 & 1424 \\
\hline 0,2 & 70 & 1173 \\
\hline 0,3 & 60 & 1005 \\
\hline 0,4 & 55 & 921 \\
\hline
\end{tabular}

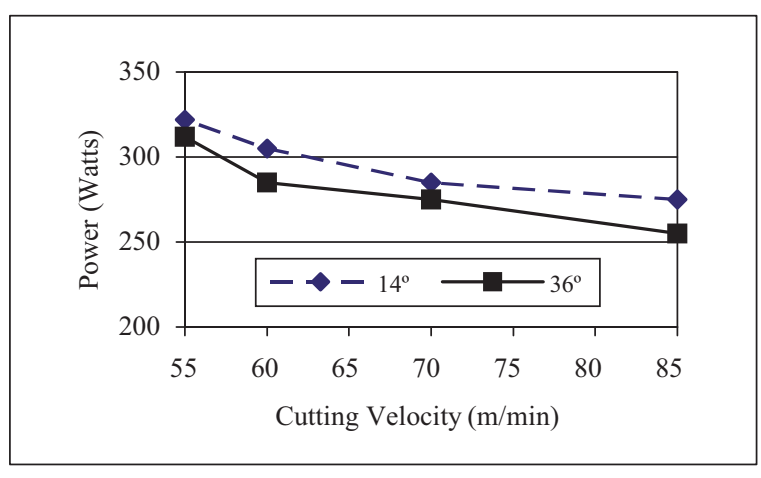

Figure 3. Power consumption versus cutting velocity for bronze $\mathrm{S}_{1}$. Cutting tools with differents rake angles.

The effect of the cutting velocities for bronze and brass using different rake angles is shown in figures 3 and 4 . Again in both samples, lower power consumption corresponds to the cutting tools with the rake angle from Bill Mundy theory.

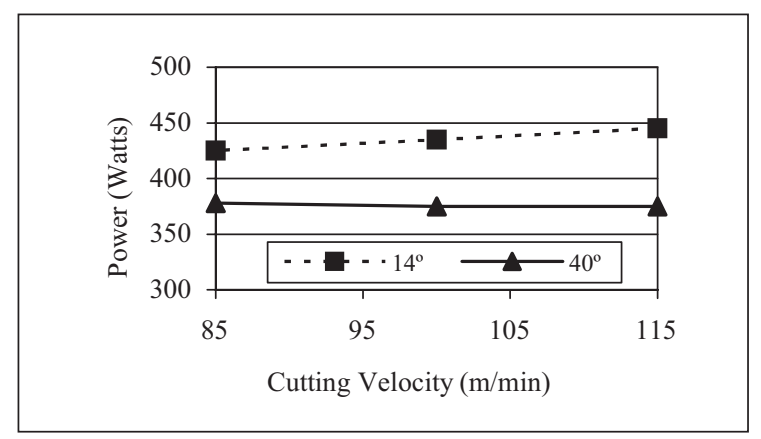

Figure 4. Power consumption versus cutting velocity for brass $\mathrm{B}_{1}$. Cutting tools with differents rake angles

\section{CONCLUSIONS}

The cutting tools with effective rake angle recommended by Bill Mundy theory show lower power consumption for brass and bronze.

The less power consumption increased with cutting velocity of the tools with the effective rake angle obtained from Bill Mundy theory.

The lower power consumption of the experimental effective rake angle tools determined by Bill Mundy theory can be explained by the cutting edge working more freely. 


\section{REFERENCES}

[1] F. Mason. "How does a metal want to be cut?" Associate editor. American Machinist, pp. 57-61. July 1987.

[2] A. Colque, A. Coria, J.M. Godoy and J. Vergara. "Bill Mundy theory-copper mechanized with drilling and tapping tools". $6^{\circ}$ Congreso Binacional Conamet/Sam 2006. Santiago, Chile. 2006.
[3] N. Larburo N. "Máquinas. Prontuario". 2a Edición. Ed. Paraninfo. Madrid, España. 1990.

[4] H. Jütz, E. Scharkus and R. Lobert. "Prontuario de Metales". Tablas para la industria metalúrgica. Ed. Reverté S.A. Barcelona, España. 1996.

[5] Sandvik Coromant. "Herramientas para tornear". AB Sandvik Coromant. Sweden 2000.

[6] F. Mason. "Positive inserts propel productivity". Manufacturing Engineering, pp. 27-31. January 1995. 